\title{
Theorising International Trade Unionism
}

\author{
Keith Abbott, Deakin University
}

\begin{abstract}
This paper uses neo-functionalist and institutionalist theories of geo-political integration to develop a theory of international trade unionism. In brief, the theory asserts that the type of international 'context' in which international trade unions operate presupposes the types of 'imperatives' that will dominate their interests and concerns. These imperatives are taken to operate along one of three dimensions - industrial, political and ideological, and are seen as evolving in accordance with the 'logic of spill-over' in global and sub-global integration processes. Using this interpretation the discussion provides reasons as to why ideological imperatives have historically dominated international trade union thinking, the only significant exception being regional trade unions operating in Europe, which have evolved beyond the ideological to embrace industrial and political imperatives in their modes of organisation and operation.
\end{abstract}

\section{KEY WORDS}

ETUC, ITUC, international trade unions, neo-functionalism, theory

\section{Introduction}

Theories of trade union organisation and behaviour are typically concerned with explanations and analysis that are situated in a national context (e.g., Poole 1981, Martin 1989, Moses 1990, Kaufman 2010). By comparison, theories of trade unions operating at an international level have a relatively sparse literature (however, see: Lorwin 1953, Levison 1972, Logue 1980, Busch 1983, Cohen 1987, Hyman 2002, Herod 2003, Ghigliani 2005). There are good reasons for this division of attention. As objects of research national unions are more numerous, deal more directly with workplace industrial relations and are far more accessible than their international counterparts. It is also far easier to identify the major influences that shape the character and development of trade unions operating within the geo-political confines of the nation-state. The following discussion seeks to make some in-roads into this relatively neglected area of research by developing a theory of international trade union organisation and behaviour. In so doing the discussion first sets out the different types of global and sub-global 'contexts' in which international 
trade unions operate, as well as the associated 'imperatives' that come to dominate their interests and concerns. The discussion then goes on to show why ideological imperatives have historically dominated international trade union thinking, but notes some cursory movement towards the adoption of political imperatives at the global level, and a more definitive shift towards the same imperatives occurring at the sub-global level among international trade unions operating in Europe.

\section{Contexts and Imperatives}

Much of the industrial relations literature fails to distinguish between different types of trade union. The functions and concerns of national occupation and industry trade unions (hereafter simply referred to as national sectoral unions), for instance, has often been assumed to be the same as those of national trade union confederations (hereafter referred to as national union confederations)(e.g. Ball and Millard 1986 chapter 4, Fairbrother 2000, Aidt and Tzannatos 2008). Yet the assumption that different trade union types share common modes of organisation and behaviour cannot be sustained. Employees organised at the level of the workplace invariably act and hold concerns that differ to those undertaken and held by the sectoral unions to whom they belong. National sectoral unions similarly act and hold concerns that differ to those of national confederations (e.g. Martin 1980). Were it otherwise there would be few reasons for the division of responsibility that comes to exist within the hierarchy of trade union relationships (Crouch 1982). This being the case it is worthwhile to distinguish international trade unions from other types of trade unions organised at the national level.

In terms of the geo-political scope of their operations and affiliations there are four types of international trade union. The first engage in transnational exchanges and affiliate national union confederations from countries that need not be geo-politically contiguous. Most prominently represented in this group are the International Trade Union Confederation (ITUC) and the World Federation of Trade Unions (WFTU), and less prominently the Southern Initiative on Globalisation and Trade Union Rights (SIGTUR). The second type trade union international similarly engage in transnational exchanges along the same geo-political dimensions, but affiliates national sectoral unions rather than national union confederations. Examples represented in this group are the International Federation of Chemical, Energy, Mine and General Workers Union, the Fédération International du Personnel des Services Public and the Trade Unions International of Transport Workers, each of which affiliate nationally organised sectoral unions. Because these two types of international trade union cover countries from all parts of the world, it can be said that their organisation and operations are global in scale.

The third type of international trade union affiliates national union confederations from countries that are geo-politically confined or contiguous. Examples of this type are the European Trade Union Confederation (ETUC), the Central Americano de Trabajadoras (CLAT) and the International Confederation of Arab Trade Unions, each of which affiliate national union confederations drawn from within a definable geo-political region (e.g. Europe, the South America and the Middle East in the examples cited). The fourth type similarly engage in transnational exchanges within a definable geo-political region, but affiliate nationally organised sectoral unions 
rather than national union confederations; the European Metalworkers' Federation and the South American Federación Latinamericana de Trabajadoras Jubilidados y Penionados being two such examples. Because these latter types of international trade union cover countries within a contiguous geo-political region, their organisation and operations can be said to be sub-global in scale.

Having set out the different types of international trade unions the theory argued in the following centres on the proposition that the types of 'imperatives' that dominate their activities and concerns depends on the type global or sub-global 'context' in which they exist, and that these imperatives operate along three dimensions. The first is where a global or sub-global industrial context exists, which can be identified in situations where the majority of multinational companies operating either globally or sub-globally are willing or forced to engage international trade unions on a transnational basis. In such circumstances the organisation and behaviour of an international trade union will be predicated on industrial imperatives. By this it is meant that its existence and basis of support will be predicated upon the ability to achieve material gains for members through the type of cross-border relations held with multinational companies, whether these relations are cooperative or adversarial, or whether the companies concerned are operating globally or subglobally. This can involve the organisation of transnational collective bargaining and associated industrial action, the provision of representation on the consultative committees of companies, whether national or multinational, or any other activity aimed at improving the material interests of workers employed in these organisations.

Where no such context exists other imperatives will come to the fore. Thus, a second dimension emerges where a global or sub-global political context exists, which can be identified in situations where constituent countries have ceded certain aspects of their domestic political sovereignty to a global or sub-global polity (e.g. the United Nations and the European Union respectively). In this instance an international trade union's existence and support will be predicated upon its ability to achieve political gains through the type of relations it holds with a global or subglobal polity. This can involve accessing global or sub-global policy makers to influence legislative outcomes favourable to the interests of affiliated trade unions and/or those they represent, providing representation on the policy committees or such polities, undertaking public campaigns aimed at influencing the policy deliberations of the polities, or any other activity aimed at securing policy measures that advance the interests of affiliated organisations and/or those they represent. In other words, the international trade union's existence and support will be predicated upon political imperatives.

A third dimension is where no global or sub-global industrial or political contexts exist, in which case an international trade union's existence and support will be based upon less concrete imperatives. These can be termed as ideological, defined as a union's coherent set of ideas about the organisation and governance of society and its improvement, and the appropriate role of trade unions in securing that improvement (Blattberg 2009). This imperative has two sides. The first is educative, which involves raising awareness about the world view held by the trade union. This can involve calling public attention to perceived injustices committed by national governments or multinational employers, or appealing to the wider international community to exert moral pressure on behalf of affiliated unions or members holding the same ideological disposition. It can also 
involve strategies designed to promote cultural exchanges and experiences that build common empathy towards a particular vision of the world, or the organisation of transnational campaigns aimed at providing members of affiliated organisations with a sense of common identity and purpose towards that vision. The second side takes the form of material assistance, which more simply involves the provision of financial and other types of logistical support to strengthen the position of member unions sharing the same view of the world represented by the international trade union (Note: the 'context determined' concept used here draws on a theoretical characterisation of collective bargaining hierarchies first formulated by Clegg 1976).

Setting out these distinctions is not to imply that the organisation and behaviour of international trade unions will be dominated by a single imperative to the exclusion of others. Like all unions, international trade unions inevitably subscribe to some form of ideological conviction, hold expectations of developing substantive relations with companies, whether national or multinational, and seek to exert political influence wherever possible. Nor is it to say that a single imperative will dominate over others under all circumstances at all times. Periodic campaigns conducted by trade unions at all levels typically involve multiple activities undertaken through different avenues, such that it is not unusual for political lobbying to be engaged in combination with industrial action, whether directed at nationally or transnationally (e.g. Turnbull 2007) - the political and industrial imperative combined, if you like - or to revert to industrial action once political lobbying has failed. The point to be made is that outside these periodic disturbances it will be the prevalence of global or sub-global industrial or political contexts, or lack of them, that can be expected to promote one imperative over others as the foundation upon which an international trade union's principal activities, concerns and support will be based. To the extent that global and sub-global contexts are capable of evolving over time it is also possible for the imperatives as a foundation for trade union behaviour and support to change; and this is the central point the theory presented here is arguing.

This three dimension theory can be given a degree of dynamism by drawing on the literature relating to neo-functionalist theories of international integration. The most elaborate and most criticised theories of this type came to prominence in the 1950s (e.g. Haas 1958) and 1960s (e.g. Lindberg 1963) as a means of explaining the early economic and political development of the European Union (EU), then known as the European Economic Community (EEC). Briefly, such theories held that the integration of one industrial or business sector within a country will provide its own impetus and spread to complimentary or associated sectors in other countries, such that transnational institutions established to coordinate and/or administer specific economic tasks between nations will set in motion economic, social and political pressures for further integration. Called the 'logic of spill-over' (or more specifically, 'the expansive logic of sector integration'), three developments are said to epitomise this snowball effect. The first involves a functional spill-over, in which the technical characteristics of economic tasks undertaken within different countries become so interdependent that it becomes impossible to treat them in isolation. Attempts to integrate the tasks lead to economic problems which can only be solved by integrating more and more tasks, beginning at the national level and eventually spilling-over to the transnational level. As these processes unfold an impetus is provided for 'negative integration' (e.g., tariff reduction policies), which are later supplemented by more complex forms of 'positive integration' (e.g. coordination 
policies). The need to manage the problems associated with these policy developments in turn lead to a political spill-over as government leaders, public officials and private elites undergo a learning process which culminates in a collective perception that their interests will be better served by seeking transnational rather than national policy solutions. This perception is made possible as processes of 'bureaucratic interpenetration' and 'informal cooptation' emerge from the efforts of public and private elites seeking to manage the problems of functional spill-over. The result is the establishment of intergovernmental political institutions and eventually fully fledged supranational institutions. As these institutions develop and grow they are held by neo-functionalist to generate new pressures which lead to a cultivated spill-over. In this final stage the traditional nationallyorientated expectations and loyalties of political and business elites are ultimately transformed, leading them to call for ever-more comprehensive forms of transnational integration and for the establishment of ever-more powerful supranational institutions to govern their processes.

Neo-functionalist theories applied to European integrative processes fell into disfavour during the 1960s (e.g. Hoffman 1966, Moravcik 1993, Rosamond 1999), but re-emerged in the 1990 s as a means of explaining the EU's drive to implement its Single Market project (e.g. Transholm-Mikklesen 1991, Conzelmann 2003, Eilstrup-Sangiovanni 2006, Hooghe and Marks 2006, Mansour 2011). It is useful to address these criticisms and account for the more recent revival before moving to adopt the concept in the theory being presented here. Criticisms of neofunctionalism emerged over the 1960s when the European integrative process began to stall. President De Gaulle's veto of British membership in 1963 and France's withdrawal from engaging in EEC business in 1965 were early events that appeared greatly at odds with the 'logic of spill-over' (Hoffman 1966). Haas (1976) himself noted how the 'Eurosclerosis' that had set in over 1970s as a result of the world oil crisis and global stagflation had undermine the scope and desire of European policy-makers to adopt predictable integrative measures. Later criticisms suggested that neofunctionalism offered little in accounting for how European governments actually made choices between competing policy options (Moravcsik 1993), and that it failed to take proper account of how supranational institutions and multinational companies shaped national political attitudes towards regional integration (Rosamond 1999).

As a consequence of these failings a more refined neo-functionalism emerged that focused on the evolution of European institutions and their mode of governance, rather than seek to 'grand theorise' about the overall processes of European integration. The impetus for this focus and revival was the signing of the Single European Act in 1986 and the Treaty of Maastricht in 1992, both which saw the pace of European integration gain significant momentum (e.g. Sandholtz and Fligstein 2001). Eilstrup-Sangiovanni (2006), for instance, found that 'functional spill-over' was clearly in evidence in the reasoning behind EU member states deciding to formulate and sign the two instruments. The need to remove tariff barriers was initially necessary to facilitate flagging trade between EU member states, which in turn generated a business need for the harmonization of product standards across national boundaries. This in turn saw national governments cede power to the European level to coordinate this harmonisation. Sandholtz and Stone Sweet (1998) similarly found that as the rate of transnational exchanges increased as a result of these instruments, so also did the interest of those involved in such exchanges mellow towards the need vest authority with the EU's governing institutions (i.e. the European Commission, European Council, European 
Court and European Parliament). This was because these institutions became the source of rules and regulations relevant to their needs. To the extent that this occurred, these observers argue that it was at the growing expense of national political sovereignty. And although some member states may have tried to slow the process, they met with only limited success, precisely because of the unavoidable logic of growing functional exchanges spilling over to create a necessary political context to govern the exchanges.

The present analysis adopts this more modest form of functionalism, in that the focus is on the evolution of political authority embedded in the EU's governing institutions. The authority vested in supranational institutions to govern and coordinate transnational economic and political integration of the type that operate in the EU is taken as the centre-point of our theory of subglobal economic and political integration. In line with the 'logic of spill-over' consistent with this type of integration, the notion of global and sub-global 'contexts' is coupled to provide a means of theoretically postulating how international trade union 'imperatives' might be expected to evolve.

\section{International Trade Unions}

In moving to apply the theory it is first useful to say something about the structure, aims and activities of international trade unions. This can be done by making reference to three competing visions of trade unionism around which the international trade union movement have divided over the post-war period.

The first vision is represented by the World Federation of Trade Unions (WFTU), which, for much of the period in question, subscribed to a communist form of trade unionism that sought to raise workers to a level of revolutionary class-consciousness. Established, organised and dominated by the former Communist Party of the Soviet Union, the WFTU was guided by the principles of militant class struggle. In relation to working class movements in capitalist counties, it opposed national monopolies and multinational corporations, cultural imperialism and regional integration projects, as well as colonialism and more generally the exploitation of workers under capitalism (i.e. it pursued an educative ideological imperative). In these endeavours it was an integral part of the Cold War politics of the early post-war years. The WFTU also provided financial and other forms of support for working class struggles in former colonial countries (i.e. it pursued a material support-based ideological imperative). It drew the bulk of its membership from national union confederations operating in former Eastern Bloc countries. There were also important member confederations from Europe, as well as a number of confederations from former colonial countries. The WFTU also directly controlled several Trade Union Internationals (TUIs) that represented national sectoral unions. These latter organisations had broadly the same coverage as the WFTU and engaged in broadly similar activities (Busch 1983). The aims and activities of the WFTU and TUIs mellowed in providing material support after decolonisation and ceased altogether with the collapse of the Soviet Union. They have since continued to propagate a revolutionary form of unionism and they still engage in educative measures to achieve this end. The bulk of present-day membership is still drawn from former Eastern Bloc countries and current communist countries (e.g. China, Vietnam and Cuba). And there is still a significant number of 
member confederations from former colonies in Africa, the Middle East and Asia, to which a smattering of trade unions from parts of South America can be added; in short, from countries having historical associations with either communism or imperialism (WFTU 2011). The coverage, role and influence of the WFTU and its associated TUI are now negligible, such that a communist vision of trade unionism can be said to play an insignificant role in international trade union developments (Ashwin 2004).

The second vision worth noting is represented by the former World Confederation of Labour (WCL), which subscribed to a Catholic socialist form of trade unionism. The WCL supported the ideals of class collaboration, the spiritual welfare of workers, co-determination in industry and private property ownership, and it drew the bulk of its membership from Belgium, the Netherlands and Latin America; in short, from those countries where Catholicism has had a strong religious presence. It also coordinated the activities of several Trade Internationals (TIs) which represented national sectoral unions subscribing to Catholic socialist ideals, and it operated a number of regional committees in Africa, South America and Asia. For the most part the activities and influence of the WCL, its TIs and its regional organisations were greatly circumscribed by a lack of resources, negligible support and limited coverage of the workforces in the countries were they operated. As such, they were confined to providing educative support for affiliated trade unions seeking to compete for members against trade unions that held class-conflict or secular orientations towards workplace relations (i.e. it pursued an educative ideological imperative)(Roberts 1976). The growing secularisation of Europe after Vatican II, the most important region in terms of its source of membership, leadership and finance, saw the fortunes the WCL and its associated TIs and regional committees decline to the point where they were forced to amalgamate in 2006 with the then International Confederation of Free Trade Unions (Traub-Merz and Eckl 2007).

The third vision of trade unionism is represented by the ICFTU, which after amalgamating with the WCL became known as the International Trade Union Confederation (ITUC). The ITUC and its forerunner subscribed to the ideals of democratic socialism. It supported the concepts of independent trade unionism and workers' rights to free association and collective bargaining. It also supported industrial and political democracy, as well as welfare capitalism. It held, and still holds, close associations with Global Union Federations (GUFs), which affiliate national sectoral unions subscribing to the same ideals. The ITUC's most important regional organisations are the Inter-America Organisation of Workers (ORIT), which covers the Americas, the African Regional Organisation (AFRO), which covers Africa, and the Asia Pacific Regional Organisation (APRO), which covers Asia (ITUC 2011). The ETUC, which represents trade union interests in Europe, has been organisationally independent of the ITUC since its inception in 1973, though it has shared the same social democratic ideals and regional aspirations since its foundation (Roberts 1976); indeed the two organisations presently share the same building in Brussels. The ITUC has historically been largest, wealthiest, and most important international trade union in terms of its global coverage and influence. Its main areas of activity have involved drawing world attention to injustices committed by national governments that supplant workers' rights and the organisation of independent trade unions. It also lobbied national governments in support of measures to improve the material welfare of workers, and it opposed communist and Christian socialist forms of trade 
unionism when and where these offered competition for the allegiance of workers (i.e. it pursued an educative ideological imperative). As such, its activities and aims have never extended to seeking the overthrow of capitalism or limiting the operation of multinational companies, nor have they sought to improve the moral and spiritual well-being of workers in the manner of the previously mentioned trade union internationals (Weisband 2000)

Before leaving this section it is worth looking briefly at the 'contexts' in which these internationals have operated over the post-war period. In doing so it is useful to divide the period. During the early post-war years multinational corporations were highly successful at resisting the cross-border activities of international trade unions, such that a transnational industrial context, whether global or sub-global, was either weak or non-existent (e.g. Taylor 1999). The same could be said of global and sub-global political contexts. The Trade Union Advisory Committee of the Organisation for Economic Cooperation and Development (TUAC-OECD) and the International Labour Organisation (ILO), for example, were moribund as agencies for advancing the transnational material interests of workers, whilst sub-global polities (e.g. Association of South East Asian Nations, Southern African Customs Union) were confined to dealing with commercial and trading matters only, having few powers to deliberate on social and labour issues of any substance (Charnovitz 1987). Under these global and sub-global industrial and political circumstances, it is hardly surprising that both global and sub-global international trade unions seeking to attract or maintain membership support had little option but to act as standard-bearers for one of the major international working class ideologies: communism, Catholic socialism and democratic socialism. Cold war politics, the volatility of colonisation and the still powerful draw of Catholicism over the early post-war years only served to sharpen this divide.

The decolonisation of Africa and Asia in the 1950s and 1960s, the growing secularisation of the west after Vatican 11 and the collapse of communism in Eastern Europe in the 1990s, combined to greatly weaken the ideological divide between the aforementioned internationals (Ashwin 2004). At the same time the ascendency of neo-liberal and neo-classical political and economic ideas in national policy thinking saw significant reductions in tariff barriers, which in turn facilitated the globalisation of national business and financial processes. These developments were also facilitated by rapid advancements in transportation, communication and information technologies (Giddens 2002). The resultant growth and expansion of multinational companies brought many benefits, but it also served to raise concerns about the impact of their operations. National governments fearful their sovereign policy abilities were being eroded by the processes of globalisation and equally fearful of the electoral ramifications of unethical behaviour on the part of multinational companies, together with well publicised civil protests against both (De Bettignies and Lepineux 2009), steadily saw space emerge for the development of a nascent global political context.

By way of example, over the 1990s ILO Conventions (2011), most of which had long been in existence, many of which had only been adopted in name or else ignored, began to be used as guides for the provisions contained in Corporate Social Responsibility policies developed by multinational companies; their way of quelling national government concerns, warding off international trade union criticisms and proving their ethical credentials to shareholders and customers (Kolk et al. 1999). More telling, the ILO's Core Labour Rights resolutions came to 
similarly used as a guide for the provisions contained Global Framework Agreements concluded with GUFs (Hammer 2005). Over the past decade, the ITUC has furthermore become engaged with the ILO and its Decent Work Programme, aimed at promoting the rights of workers, and particularly the rights of workers employed in multinational companies operating in the developing world. In still another example, the widely publicised and often violent public protests over the activities of the WTO have heighted internal debate among its membership over the inclusion of labour standards provisions in its trade agreements (Grace 2005). This development has in recent years encouraged the ITUC to extend its own version of the Decent Work Campaign in this direction, it lobbying the WTO to include such provisions in transnational trade agreements concluded under its auspices (ITUC 2007).

In all these examples the developing elite interaction at the global political level is suggestive of an emerging global political context, which, in combination with the collapse of the ideological divide between international trade unions, might be said to evidence a reorientation of their concerns and activities towards more overt political imperatives. The shift is nonetheless weakly founded. The ITUC's Decent Work Campaign has so far yielded little outside of calling public attention to the need to support basic workplace rights through coordinated 'days of action'. What success has been realised is with European Commission and European Parliament, both of which have acknowledged the need to support workers' rights (SOLIDAR 2009). But this is at a subglobal political level in a region where such rights are already enshrined in regional and national laws. More decisively the ITUC's Campaign of lobbying the WTO may be said to evidence a growing level political interaction in the ITUC's strategic mix, but actions in this direction have so far gained little purchase in realising the inclusion of provisions enforcing workers' rights in trade agreements. Global Framework Agreements might also be so considered, but fewer than a couple of hundred have been concluded, most of which have been with multinational companies headquartered and operating in Europe, and have offered little beyond affirming workers' rights in a part of the world were such rights are already a part of doing business legally (Stevis, 2010). The most that can be said is that the 'logic' is in evidence, unfolding in a manner consistent with the theory being presented, if only weakly founded. Yet the noted successes in Europe, however weak, draw attention. For they are certainly wrapped up with wider developments occurring is the region which offers more definitive evidence in support of the theory. It is to these developments that we now turn.

\section{Sub-Globally Organised International Trade Unions - The Example of the ETUC}

Sub-globally organised international trade unions operating in Europe are an important and more definitive exception to the observations made above in relation to their globally organised counterparts. The ETUC, for example, affiliates national confederations in a sub-global region (i.e. Europe) where there exists a sub-global political context (i.e. EU) of some significance. It is significant in the sense that the EU has a legal identity where settled legislation is binding and often comes into existence without necessarily passing though the political apparatus of member states. It is significant, also, in that the governing institutions of the EU have a mandate which extends 
beyond purely trade and commercial matters to include issues such as political union and social cohesion (Hix 2005). In the longer term absence of any substantive industrial context, the ETUC has to some extent always depended upon the promotion of a particular vision of trade unionism, in this case the cause of social democratic trade unionism, but it has also depended upon the ability to act as a political intermediary between its member organisations and the institutions of the EU (Kirchner 1977). Over the course of its history, however, the nexus between ideological imperatives and political imperatives has been far from balanced. Ideological imperatives, for instance, were prominent during the period surrounding the ETUC's foundation in 1973, both as a means of determining the criteria for membership and for the settlement of organisational policies (Windmuller 1976: 44-5). Political imperatives were of secondary importance, not least because the integrative processes of the EU at this time had stalled (Williams 1990: 299-300), and only came to the fore during mid-1980s in response to the EU's moves to implement its Single Market programme and improve the democratic dimensions of its institutions (Abbott 1997).

This shift has since been reflected in what can only be described as a developing symbiotic relationship between the ETUC's internal political relations and the type of external political relations it has been able to develop with the institutions of the EU. As the ETUC's 'imperatives' have come to rest more squarely on political objectives specified in claims made upon EU legislators, there has been an implied demand made on its part for increasing levels of political authority from affiliates to speak and act on their behalf. The generally favourable reactions of European legislators to such claims, evidenced most notably in the policies of inclusion under the Val Duchesse and Social Protocol processes (European Communities 1992), as well as the 'Social Dialogue' rights issuing from the Charter of Fundamental Rights of the European Union (European Communities 2000), has seen the ETUC's external political legitimacy (or its external political imperative, if you like) steadily grow. This, in turn, has seen the ETUC's internal political authority (or its internal political imperative) similarly grow as affiliated organisations have come to perceive its claims are being increasingly recognised by European legislators (Note: the use of this type of external and internal dynamic is drawn from a characterisation of the political development of Britain's Trades' Union Congress first identified by Martin, 1980, chapter one). In short, the accelerated integrative processes of the EU over the past decade and a half has extended the logic of spill-over beyond government and business elites to include the leadership of this important representative of European labour, with member organisations coming to rely more and more upon it as a political intermediary for advancing their interests at the regional and national level (Marginson and Sisson 1996: 11; Cohen and Richardson 2009).

This line of thinking plays itself out nicely in the findings of a recent study by Bieler (2006), which looks at the behaviour of national trade unions since the implementation of the European Monetary Union. Bieler (2006) found that national trade unions covering workers employed in multinational companies were more likely to support a single currency than those covering workers employed in national companies. This was because multinational companies were the major beneficiaries of the monetary stability and facilitation of trade afforded by a single currency, and by association so also the workers in their employ. Pertinent to the present discussion, for those trade unions covering workers employed by multinational companies, the operation of a single currency had served to diminish the relevance of national industrial relations 
options and avenues of policy influence, such that they were more likely to consider cross-border campaigns designed to influence EU policy processes. This contrasted with national trade unions covering workers employed in national companies, where it was found that national unions were more inclined to operate through national industrial relations systems and national policy processes, and were accordingly less interested in engaging in cross-border cooperation with other unions to influence EU policy outcomes. The evidence provided in the study thus supports the contention listed above that trade unions facing diminishing opportunities within their national spheres of influence will be more likely to endorse coordinated activities at the regional level.

It can be argued from this brief synopsis that as the 'globalising' processes of economic and associated political integration unfold an impetus is provided for international trade union 'imperatives' to undergo a transition. In the case of the ETUC the transition has been from the ideological to the political, and has been predicated upon the existence (or developing existence) of a significant sub-global political 'context'. Or to put its case in general theoretical terms, the 'imperatives' of sub-globally organised international trade unions may be historically, or in the first instance, dominated by ideological concerns, but as the processes of sub-global regional cooperation and integration unfold in a manner consistent with the 'logic of spill-over', there will be a natural transition to political concerns. The course and timing of this transition, however, will be dependent upon two factors. It will first be contingent upon where the loci of effective political authority resides in the administration of a transnational polity at any given time; and second, it will be dependent upon the type of matters governed by the polity (Note: these two points draw on the pressure group theory of Eckstein 1960, chapter 1). If, for example, the structure of authority is dominated by inter-governmentalism and the matters administrated are limited to commerce and trade (e.g., conditions which marked EU political processes prior to the mid-1990s), then the subglobally organised international trade union will be disposed to rely on its affiliates and their national channels of action to support what will ostensibly be its labour and social demands. Its internal political authority will be low as a consequence of this reliance, which in turn will be to the detriment of its ability to influence the governance and outcomes of the sub-global polity. In such circumstances, ideological imperatives will more likely dominate the union's basis of support and appeals for membership action, with political imperatives being of secondary importance. If, however, the structure of political authority is dominated by supranationalism and the matters administered extend to labour and social issues (e.g. conditions which reflect more recent trends in EU political processes), then the converse set of conditions are likely to be more operable, with political imperatives coming to the fore and ideological concerns being relegated to a lower level of importance. It follows from this that if the 'logic of spill-over' unfolds as expected, or in a manner consistent with the historical development of the $\mathrm{EU}$, then the movement in trade union imperatives will be from the ideological to the political. On the evidence of Bieler's (2006) study mentioned earlier, there is much to support this thesis.

It remains to say something about sub-global industrial contexts and international trade unions affiliating national sectoral union. In this regard there is little in terms of precedent upon which to make any definitive statements, theoretical or otherwise. As previously stated, few, if any, international trade unions can claim their existence and support is principally based upon the ability to achieve material gains through cross-border bargaining relations held with multinational 
companies. Yet there is some evidence of an industrial context emerging under the umbrella of the type of emerging political context mentioned above in relation to the EU. In this regard we refer to the European industry committees of GUFs, which over the past couple of decades have been integral to the establishment of transnational information and consultation forums within multinational companies operating within the EU (Pulignano 2011). Whilst this offers an exceptional example of sub-global international trade unionism being dominated by industrial imperatives, it needs to be weighed against the fact that the powers of these information and consultation forums in the decisional structures of multinational companies are minimal and that on-going trade union involvement in their processes is negligible (Abbott 1998). What is clear, however, is that the establishment of such forums also owes much to the political desire on the part of the EU to implement its Single Market programme in a socially acceptable manner. The passing of the European Works Council directive in 1994 was an early reflection of this desire, making it possible for European industry committees to operate via the legal requirement for European multinational companies to engage workers and their representatives in negotiations over the implementation of transnational workers councils (Faulkner 2006).

The point to be taken here is that the establishment of a global or sub-global political context appears to be a necessary precondition for the emergence and maintenance of a global or sub-global industrial context. Thus, just as a nexus could be said to exist between the ideological and the political in the way international trade unions deal with the existence or non-existence of a global or sub-global polity, so also could it be argued that a nexus seemingly exists between the political and the industrial in the way international trade unions deal with significant and insignificant global and sub-global political contexts - 'significant' here meaning a context in which a transnational polity has supranational powers to deliberate on labour and social matters of some substance, as opposed to 'insignificant', where the global or sub-global polity is governed by intergovernmentalism and confined to dealing with commercial and trading matters only. It follows from this, that the movement in international trade union 'imperatives' will typically run from the ideological to the political, and only then from the political to the industrial. This thesis is depicted in Table 1, with the most likely transition of Dominating Imperatives moving typically from top to bottom as the Global or Sub-Global Contexts change in accordance with the 'logic of spill-over'.

\section{Table 1. Regional Contexts and Dominating Imperatives}

\begin{tabular}{ll}
\hline Global and Sub-Global Contexts & Dominating Imperatives \\
\hline No industrial or political contexts & Ideological \\
No transnational polity exists with & Activities and support based on advancing a \\
the power or mandate to deliberate & particular philosophical view of trade unionism - \\
on issue of interest to the regional & for example, financial, organisational and \\
trade union movement, and few & educational assistance provided to member \\
multinationals are willing and able & organisations, as well as moral appeals to \\
to recognise and engage in & the wider international community \\
transnational trade union bargaining &
\end{tabular}


Insignificant political context

Transnational polity has intergovernmental legislative powers and is confined to deliberating on trade and commercial matters of indirect interest to the trade union movement.

\section{Significant political context}

Transnational polity has supranational legislative powers and in addition to deliberating on trade and commercial matters has the power to deliberate on labour and social matters of direct interest to the trade movement.

Industrial context

Majority of multinational companies willing to bargain with trade unions on a transnational basis
Ideological (primary)/political (secondary)

Activities and support primarily based on advancing a particular philosophical view of trade unionism, this supported by secondary efforts to galvanise internal interest among member organisation to act collectively in national frameworks to pursue agreed labour and social causes.

\section{Political (primary)/industrial (secondary)}

Activities and support primarily based on advancing the interests of member organisations through political gains made through lobbying activities and channels of access to transnational policy makers, this supported by secondary efforts to encourage social and labour policies that legitimise transnational bargaining frameworks

Industrial

Activities and support predicated upon the ability to achieve material gains through cross-border bargaining relations held with multinational companies

Source: Author

Before turning to the conclusion it seems worthwhile engaging a recent study that argues a case contrary to the theory being presented here. Erne's (2007) study examines what role European trade unions might play in reducing the democratic deficit of the EU. In so doing it holds trade unions to be pivotal actors in civil society, such that they are deemed to be an important agency for realising this end. The broad argument of the study finds the current technocratic strategies pursued by trade unions at the European level are inimitable to advancing the democratic credentials of the EU, and calls for a range of alternative Euro-democratisation strategies to be adopted that would focus on organising on-going European collective action as a means of creating a European public sphere and putting pressure on EU policy makers. The present top-down engagement between technocratic elites would thus be replaced by bottom-up engagement involving those most subject to EU policy outcomes, and thereby improve the democratic processes of the EU. Erne (2007) sees evidence of the latter in the emerging pattern of cross-border wage coordination occurring within the EU, and cites the examples of coordinated trade union resistance to two corporate mergers, with success being accorded to the application of democratic strategies in one instance, and failure accorded to the use of technocratic strategies in a second. The study thus argues a contrary case to the neo-functionalist thesis presented here in suggesting that an industrial context is a necessary precondition for a 'properly' functioning political context.

Erne's (2007) analysis is problematic in that it assumes trade unions are inclined to preference strategies aimed at advancing the cause of regional democracy over strategies aimed at 
advancing the core interests of workers or their own power resources. But as Mitchell (2009) rightly notes, 'unions have no a priori reason to prefer Euro-democracy over national democracy, or over technocratic outcomes in which they have special status.' Moreover the extent of European trade union coverage is hardly of a sufficient order likely to advance the cause of European democratisation, no matter what level of bottom-up collective action might be organised and undertaken. And there is still enough reticence on the part of national populations and significant competitive forces dividing national economies and their workforces, such that it is hard to see cross-border action becoming so entrenched and so widespread as to offer any sort of potent drive for improving the democratic processes of EU institutions (Mitchell 2009). In short, trade union technocratic strategies applied in a significant regional political context in accordance the logic set out in the present theory not only describes the current circumstances confronting international trade unionism operating in the region, but on the example given of sub-global sectoral unions operating in the EU would seem a necessary precondition for the realisation of the type of industrial context normatively aspired to in Erne's (2007) study.

\section{Conclusion}

Notwithstanding the exceptional example of the EU and the less than exceptional examples given in relation to the ILO and WTO, a general claim can be made about the imperatives that dominate international trade unions in term of their aims and basis of support. The present lack of industrial and political contexts globally and sub-globally means that for the foreseeable future international trade unions will be largely confined to the role of providing educational and logistical support for member organisations that subscribe to their world view. The inability to act industrially and politically in any substantive global or sub-global political environment will in turn mean that their member organisations will be unwilling to cede the authority and resources necessary for them to coordinate cross-border campaigns of any substance. In short, there is little organisational mechanism from within, nor any 'globalising' integrative stimulus from without, which will enable international trade unions to bring organised pressure and influence to bear on multinational companies and transnational polities operating either globally or sub-globally.

Some evidence contrary to this bleak claim can be said to exist in the examples of Global Framework Agreements being concluded with GUFs and the European inroads made by ITUC's Campaign for Decent Work. But in both examples there is precious little in the form of substantive outcomes that lend confidence that the need to manage the problems of functional integration is leading to a collective perception on the part of elites that their collective interests are likely to be better served by transnational rather than national policy solutions. Globalism may be driving widely-held 'free-market' ideals and notions of minimal state action, but the reality of entrenched national parochialisms still persist as a major constraint upon the possibility of supranational institution-building of the type that exists in Europe. The preservation of trade union inabilities to act transnationally still remains highly desirable among many powerful economic and political interests throughout the world. Business interests in developed countries see the possibility of greater cost efficiencies to be gained by relocating capital and operations to the developing world 
where trade union activities are tightly controlled and labour standards are kept low as a matter of state policy. And political interests in the developing world in turn see the possibility of underwriting rapid economic growth through foreign investment attracted by cheap and compliant labour (Mauzy 1997, Kuruvilla and Verma 2006). So long as these circumstances remain, the assumed automatism of the neo-functionalist model will be suspended.

This being the case, it is hard to see the role of international trade unions, aside from those operating in Europe, transiting along the trajectory theorised in this paper. From the example of the European experience, for such a trajectory to occur would require that integration processes proceed beyond their present low level commercial and trading interfaces. By this I mean that it would require the emergence of conditions in which the costs and benefits of national economic integration are more evenly spread, both geographically and functionally, in a manner similar to what exists in Europe. Or to put it another way, it is only when cross-border factor mobility comes to hinge less on the intra-system differences that one might begin to expect national parochialisms

to diminish and the technical problems of industrialisation noted by neo-functionalists to have a chance to manifest in a way which encourages business and political elites to see the need for more comprehensive forms of supranational governance. And on the theory presented here it is only then that international trade unionism will be able to move more substantively beyond its present ideological concerns.

\section{REFERENCES}

Abbott, K. (1997) 'The European Trade Union Confederation: Its Organisation and Objectives in Transition', Journal of Common Market Studies 35(3): 465-81.

Abbott, K. (1998) 'The ETUC and its Role in Advancing the Cause of European worker Participation Rights', Economics and Industrial Democracy 19(3): 605-31.

Aidt, S. and Tzammatos. Z. (2008) 'Trade Unions, Collective Bargaining and Macroeconomic Performance: A Review', Industrial Relations 39(4): 258-295.

Ashwin, S. (2004) 'International Labour Solidarity After the Cold War', in R. Cohen and M. Shirin (eds) Global Social Movements (pp. 101-117). New York: Athlone Press.

Ball, A. and Millard, F. (1986) Pressure Politics in Industrial Societies, London: Macmillan Educational.

Bieler, A. (2006) The Struggle for a Social Europe: Trande Unions and the EMU in Times of Global Structuring. Manchester: Manchester University Press. 
Blattberg, C. (2009) 'Political Philosophies and Political Ideologies', in C. Blattberg (ed), Patriotic Elaborations: Essays in Practical Philosophies (pp.3-26). Montreal and Kingston: McGillQueen's University Press.

Busch, G. (1983) The Political Role of International Trade Unions. New York: St. Martin's Press.

Charnovitz, S. (1987) 'The Influence of International Labour Standards on the World Trade Regime: A Historical Overview', International Labour Review 126(5): 565-84.

Clegg, H. (1976) Trade Unionism Under Collective Bargaining: A theory Based on Comparisons of Six Countries. Oxford: Blackwell.

Cohen, R. (1987) 'Theorising International Labour', in R. Boyd and P. Gutkind (eds), International Labour and the Third World: The Making of the New Working Class (pp. 2-25). Aldershot: Avebury.

Cohen, D. and Richardson, J. (2009) Lobbying the European Union: Institutions, Actors, and Issues. Oxford: Oxford University Press.

Conzelmann, T. (2003) 'Neofunktionalismus', in S. Schiedler and M. Spindler (Hrsg.) Theorien der Internationalen Beziehungen (pp.141-161). Opladen.

Crouch, C. (1982) Trade Unions: The Logic of Collective Action. London: Fontana.

De Bettignies, H. and Lepineux, F. (2009) 'Can Multinational Corporations Afford to Ignore the Global Common Good?', Business and Society Review 114(2): 153-82.

Eckstein, H. (1960) Pressure Group Politics: The Case of the British Medical Association. London: George Allen \& Unwin.

Eilstrup-Sangiovanni, M. (2006) 'The 1992-Project: the Revival of NeoFunctionalism and the Liberal Intergovernmentalist Challenge' in M. Eilstrup-Sangiovanni (ed), Debates on European Integration: A Reader (pp. 181-182). Basingstoke: Palgrave Macmillan.

Erne, R. (2007) European Unions - Labour's Quest for a Transnational Democracy. Ithaca: Cornell University Press.

European Communities (2000) 'Charter of Fundamental Rights of the European Union', Official Journal of the European Communities. 2000/C 364/01. Available at: www.europarl.europa.eu/charter/pdf/text_en.pdf [accessed 4 October 2011]. 
Fairbrother, P. (1999) Trade Unions at the Crossroads. New York: Mansell.

Faulkner, G. (2006) 'Collective Participation in the European Union: The "Euro Corporatism" Debate', in C. Couch (ed) The Diversity of Democracy: Corporatism, Social Order and Political Conflict (pp. 223-242). Cheltenham: Edward Elgar Publishing.

Ghigliani, P. (2005) 'International Trade Unionism in a Globalizing World: A Case Study of New Labour Internationalism', Economic and Industrial Democracy 26(3): 359-82.

Giddens, A. (2002) Runaway World: How Globalisation is Reshaping Our Lives. London: Profile Books.

Grace, B. (2005) 'WTO Trade \& Labour Standards', Foreign Policy in Focus. Washington: Institute for Policy Studies.

Haas, E. (1958) The Unity of Europe: Political, Social and Economic Forces, 1950-57. London: Stevens \& Son.

Hass, E. (1976) 'Turbulent Fields and the Theory of Integration', International Organisation 30(2): $173-212$.

Hammer, N. (2005) 'International Framework Agreements: Global Industrial Relations between Rights and Bargaining', Transfer: European Review of Labour and Research 11(4): 511-30.

Herod, A. (2003) ‘Geographies of Labor Internationalism’, Social Science History 27(4): 501-523

Hix, S. (2005) The Political System of the European Union, Second Edition. London: Palgrave.

Hooghe, L. and Marks, G. (2006) 'The Neo-Functionalists were (Almost) Right: Politicization and European Integration', in C. Couch (ed) The Diversity of Democracy: Corporatism, Social Order and Political Conflict (pp. 205-222). Cheltenham: Edward Elgar Publishing.

Hyman, R. (2002) 'The International Labour Movement on the Threshold of Two Centuries. Agitation, Organisation, Bureaucracy, Diplomacy', paper presented at the workshop on The International Labour Movement on the Thresholds of Two Centuries, Swedish Labour Movement Archives and Library, 24-25 October,

International Trade Union Confederation (2007) Decent Work Campaign - Decent Work, Decent Life, Available at: www.ituc-csi.org/decent-work-campaign-launched-in [accessed 12 August 2011].

ITUC (2011) 'About Us'. Available at: www.ituc-csi.org/about-us.html [Accessed 4 October]. 
International Labour Organisation (2002) ILOLEX Database of International Labour Standards, Available at: www.ilo.org/ilolex/english/convdisp1.htm [Accessed 12 August 2011].

Kaufman, B. (2010) Institutional Economics and the Theory of What Unions Do, Research Paper Series 10-06, Atlanta: Andrew Young School of Policy Studies, Georgia State University.

Kirchner, E. (1977) Trade Unions as a Pressure Group in the European Community. Farnborough: Teakfield.

Kolk, A., R. van Tulder and C. Welters (1999) 'International Codes of Conduct and Corporate Social Responsibility: Can Transnational Corporations Regulate Themselves?', Transnational Corporations (8)1: 143-80.

Kuruvilla, S. and A. Verma (2006) 'International Labor Standards, Soft Regulation and National Government Roles', Journal of Industrial Relations 41(1): 41-58.

Levison, C. (1972) The International Labour Movement. New York: Harper \& Brothers.

Lindberg, L. (1963) The Political Dynamics of European Economic Integration. Stanford: Stanford University Press.

Logue, J. (1980) Toward a Theory of Trade Union Internationalism. Gothenburg: University of Gothenburg Press.

Lorwin, L. (1953) The International Labour Movement, New York: Harper \& Brothers.

Mansour, N. (2011) 'Neofunctionalism and European Integration: Is it Still a Case of Spillover', eInternational Relations, Available at: www.e-ir.info/?p=11732 [Accessed 12 August 2011].

Marginson, P. and K. Sisson (1996) [revised paper] 'European Collective Bargaining: A Virtual Prospect', paper presented at the IREC Conference, Industrial Relations in Europe: Convergence or Diversification?, University of Copenhagen, 21-21 September.

Martin, R. (1980) TUC: The Growth of a Pressure Group: 1868-1976. Oxford: Clarendon Press.

Martin, R. (1989) Trade Unionism: Purposes and Forms. Oxford: Clarendon Press.

Mauzy, D. (1997) 'The Human Rights and "Asian Values" Debate in Southeast Asia: Trying to Clarify the Key Issues', The Pacific Review 10(2): 210-30.

Mitchell, K. (2009) 'Book Reviews', Industrial and Labour Relations Review (62)3: 437-438. 
Moravcsik, A. (1993) 'Preference and Power in the European Community: A Liberal Intergovernmentalist Approach', Journal of Common Market Studies 31(4): 473-524.

Moses, J. (1990) Trade Union Theory from Marx to Walesa. New York: St Martin’s Press.

Palmujoki, E. (1997) 'EU-ASEAN Relations: Reconciling Two Different Agendas', Contemporary Southeast Asia 19(3): 269-85.

Poole, M. (1981) Theories of Trade Unionism: A Sociology of Industrial Relations. London: Routledge \& Kegan Paul.

Pulignano, V. (2011) 'European Works Councils and Trade Union Networking: A New Space for Regulation and Workers' Solidarity in Europe?', in A. Blackett and C. Levesque (eds) Social Regionalism in the Global Economy (pp. 111-128). London: Routledge.

Roberts, B. (1976) 'The European Trade Union Confederation: Influence of Regionalism, Détente and Multinationals', British Journal of Industrial Relations 14(3): 261-73.

Rosamond, B. (1999), Theories of European Integration. London: Palgrave.

Sandholtz W. and Figstein (2001) (eds) The Institutionalization of Europe. Oxford: Oxford University Press.

Snitwongse, K. (1990) 'Meeting the Challenges of Changing Southeast Asia', in R. Scalapino (ed), Regional Dynamics: Security, Political, Economic Issues in the Asia Pacific Region. Jakarta: Centre for Strategic and International Studies.

SOLIDAR (2009) Decent Work, Decent Life: The Campaign So Far. Brussels: European Union/Solidar.

Stevis, D. (2010) 'International Framework Agreements and Global Social Dialogue: Parameters and Prospects', Employment Working Paper, No.47. Geneva: International Labour Organisation.

Taylor, R. (1999) 'Trade Unions and Transnational Industrial Relations', Labour and Society Programme Discussion Papers. Geneva: International Institute for Labour Studies.

Transholm-Mikklesen, J. (1991) 'Neo-functionalism: Obstinate or Obsolete?: A Reappraisal in the Light of the New Dynamism of the EC', Millennium: Journal of International Studies 20(1):1-22. 
Traub-Merz, R. and Eckl, J. (2007) 'International Trade Union Movement: Mergers and Contradictions' Briefing Papers, No.1, Bonn: Friedrich Ebert Stiftung.

Turnbull, P. (2007) 'Dockers versus the Directives: Battling Port Policy on the European Waterfront' in K. Bronfenbrenner (ed), Global Unions: Challenging Transnational Capital Through Cross-Border Campaigns (pp.117-136). Ithaca/London: Cornell University Press.

Weisband, E. (2000) 'An Empirical Analysis of International Confederation of Free Trade Unions (ICFT) Annual Surveys', Human Rights Quarterly 22(1): 167-186.

Williams, S. (1990) 'Sovereignty and Accountability in the European Community', The Political Quarterly 61(3): 299-317.

Windmuller, J. (1976) 'European Regionalism: A New Factor in International Labour', Industrial Relations Journal 7(2): 36-48.

World Federation of Trade Unions (2011) 'About Us'. Available at: www.wftucentral.org/?page_id=5\&language=en [Accessed 4 October 2011].

\section{BIOGRAPHICAL NOTE}

KEITH ABBOTT is a Senior Lecturer in Industrial Relations at Deakin University , Geelong, Australia. His published research has centred on the regional trade unionism in Europe and Asia, Australian industrial relations legislation and pressure group politics, and the theoretical and philosophical foundations of industrial relation scholarship. 